\title{
Graduate School Cyber Portfolio: The INNOVATIVE MENU FOR SUSTAINABLE DEVELOPMENT
}

\author{
Ava Clare Marie O. Robles, Ph.D. \\ College of Education, Mindanao State University, Philippines \\ ching08roblesegmail.com
}

\begin{abstract}
In today's milieu, new demands and trends emerge in the field of Education giving teachers of Higher Education Institutions (HEI's) no choice but to be innovative to cope with the fast changing technology. To be naturally innovative, a graduate school teacher needs to be technologically and pedagogically competent. One of the ways to be on this level is by creating his cyber portfolio to support students' $e$ portfolio for lifelong learning. Cyber portfolio is an innovative menu for teachers who seek out strategies to integrate technology in their lessons. This paper presents a straightforward preparation on how to innovate a cyber portfolio that has its practical and breakthrough solution against expensive and inflexible vended software which often saddle many universities. Additionally, this cyber portfolio is free and it addresses the 21st century skills of graduate students blended with higher order thinking skills, multiple intelligence, technology and multimedia.
\end{abstract}

\section{KEYWORDS}

Cyber Portfolio, E-portfolio, Innovative Menu

\section{INTRODUCTION}

Massive innovations, sustainability issues and technology upgrades have significantly changed the worldwide educational settings. Most of the problems facing the economy today are simply reflections of the lack of investment on human capital development and poor management of natural resources because education, which plays a critical role in human development and economic health of the nation, has been neglected for decades [1,2]. Unknowingly, universities, instead of being a place for good character formation has become a breeding ground for destructive social behaviour through the internet. There exists high pressure on institutions to adopt e-learning technologies, which originate from policymakers and stakeholders who are driven by political agendas reacting to demands for economic and social development.

Researchers claimed that the internet is moving into schools in the Asian region at a surprising rate. According to [3] as of March 31, 2011, the Internet users in that region had reached to $922,329,554$ which are just $23.8 \%$ compared to the world's internet users (http://www.internetworldstats.com/stats3.htm). This statistics implies that there's a big room for Asian regions to make menu advancements in technology that is supportive of sustainability mantra, by making graduate schools as the dispenser of education for sustainable development. Nowadays, students from the graduate school are using the internet to generate and obtain information, make preferences and execute skills. In response to these, Higher Education Institutions (HEI's) all over the world are making their quantum leap to cope with the increasing demands and needs brought by the internet. Nevertheless, in the process of change, HEI's need to establish a global learning arena for the students to be active contributors of sustainable development, updated with technology and be globally competitive. As a result, graduate 
schools are now making their classroom an inter-connected educational place via global networks. Hence, there is an increasing number of universities within Asian region which utilize e-portfolio as one of their means to assess students' learning. E-portfolios are used not only for assessment but also for archiving, showcasing artifacts, and recording professional development [4].

The current generation of students entering universities and colleges uses Web 2.0 applications like wikis, blogs, RSS, podcasting, and social networking in their daily lives [5]. So far, the utilization of e-portfolio is expanding, while the number of paper-pencil examinations is decreasing. Soon, e-portfolio could be an important requirement for students because of its impending force to advance students' Multiple Intelligences (MI) and Higher- Order Thinking Skills (HOTS). Conversely, in response to the planetary challenges of the 21st century, acquisition of knowledge and skills on sustainability, as well as values needed to put this concept into practice are imperative. The making of cyber portfolio as a management tool for eportfolio is one of the practical and effective actions that provide the opportunity for integration of sustainability in education blended with MI, HOTS, and technology. With this, it is vital that teachers know how to design their cyber portfolio that scale beyond traditional boundaries and executes seamlessly across different networks. This innovative know-how is actually considered as the highlight in this age with converging social, economic, ecological and technological transition.

This study is intended to bridge the gap between the emerging literatures on Education for Sustainable Development (ESD) research and to bring to light an innovative menu with tools that bring new ways of teaching Statistics blended with MI, HOTs and technology. Specifically, it sought to:

1. Find out the students' attitude towards cyber portfolio;

2. Determined the students' performance level in Statistics;

3. Determined if there is a significant relationship between students' attitude in cyber portfolio and their performance in Statistics; and

4. Designed an innovative graduate school cyber portfolio for sustainable development.

\section{RELATED STUDIES}

\subsection{Cyber Portfolio}

The sweeping growth in the use of e-portfolio generates and necessitates the need to design a management tool, such as the cyber portfolio to track students' e-portfolio with accuracy. In this study, cyber portfolio is defined as an administrative tool that manages, organizes displays and evaluates the e-portfolio of master's degree students who are situated from different localities. This can be a dashboard, a blog or a class website for linking students' e-portfolio as it facilitates the implementation of a flexible, inter-operable and scalable workflow system available on the web. One of its advantages is that it helps teachers monitor their teachinglearning processes as it provides improved output and tracking of processes for better utilization of online resources. As an administrative tool, cyber portfolio makes it possible for the teacher to:

1. gain deeper insight on sustainability issues in a lesser amount of time;

2. organize menu as a guide for students' e-portfolio;

3. showcase their students learning achievements; and

4. induce ESD key principles and concepts to students of diverse background. 
In creating a cyber portfolio, teachers can upload files, pictures, videos, photos or links to other websites. Additionally, cyber portfolio can be shared with others and published in the Web for efficiency purposes. However, students must have an account in the teachers' cyber portfolio that has been customized to meet the requirements of the student's e- portfolio. With the formulation of cyber portfolio, students and teachers are with cutting- edge technology leading to an effective teaching-learning process. For this reason, some teachers from Mindanao State University (MSU) and Notre Dame of Marbel University (NDMU) the graduate school movers of Mindanao utilize this form of innovation.

To support this innovation, educators are encouraged to design their cyber portfolio that includes original content, and links of documents for sharing or downloading with other teachers and students. By this, cyber portfolio, therefore, will not only meet the needs of educators, provide authentic evidence of students' learning outcomes and performance, but also gain knowledge and skills towards achieving a globally competitive frame.

With cyber portfolio, teachers can easily determine whether their students are going into the core of the course, because the menu found in the teacher's cyber-portfolio ensures that these basic skills are applied to higher levels of learning. It must be noted as well that menu items which appear in the teacher's cyber portfolio are hyper linked to open in separate pages or websites and that the teacher has the option and opportunity to personalize it. Fig.1 below is a sample of teacher's cyber portfolio in Statistics.

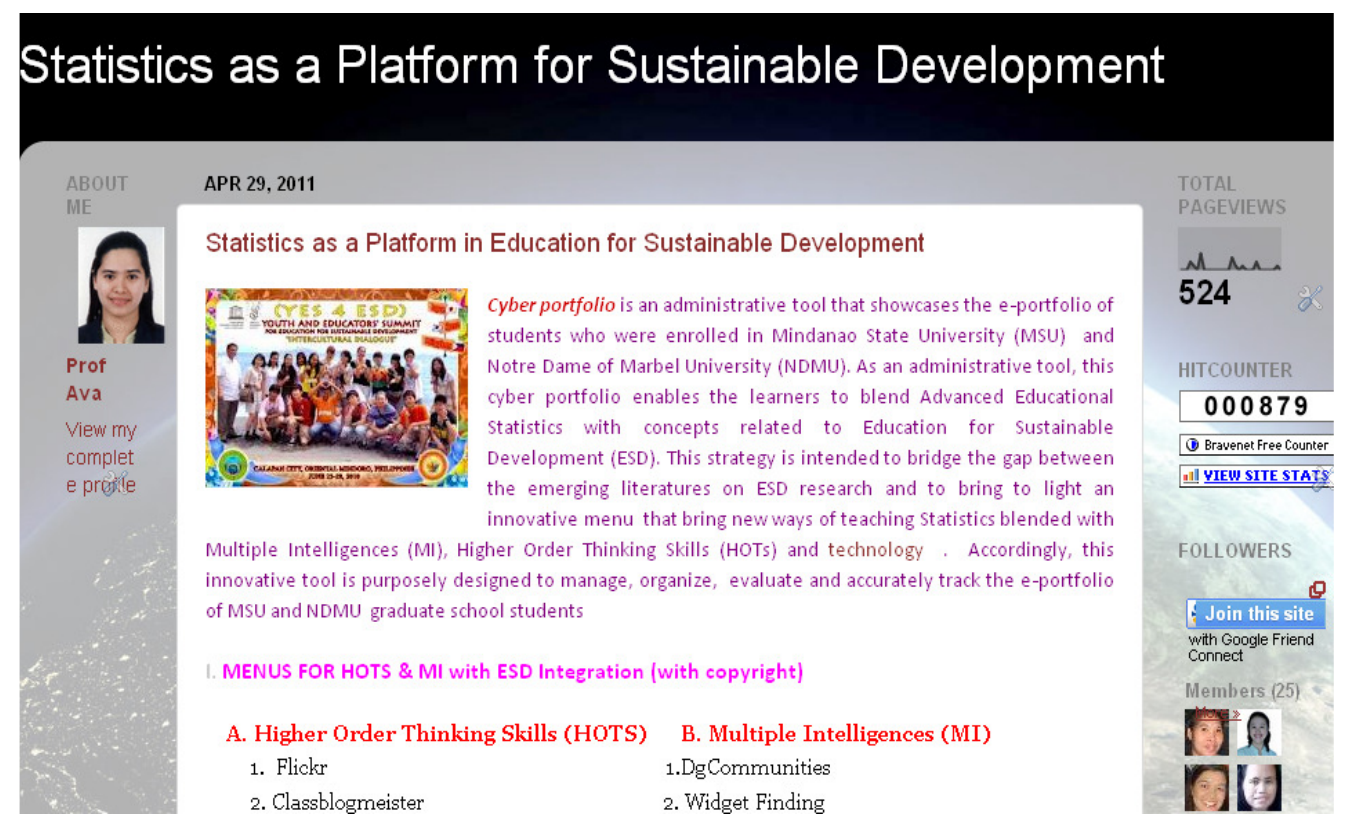

Fig .1 Sample of a Teacher's Cyber Portfolio

As an educational linking tool, it must be understood that it is the teacher's responsibility to "link" cyber portfolio into students" e-portfolio. This linked then helps teachers in tracking or monitoring students' work as it provides first hand evidence of progression, and coherence towards course completion. This proof has to be reflective in nature, which may contain hypermedia links to students' e-files. 
In this study, completed outputs from the students are structured and linked specifying that they have sought guidance from the teacher on how the content and structure of their e-portfolios are formulated. None of them had experienced personal development planning or e-portfolio construction. While students are in the process of completing their portfolio, they link it with their peer learning group for evaluation and comments. This encourages social networking, a process that is repetitive in nature and provides feedback about learning.

\subsection{E-Portfolio}

Nowadays, technology is embedded into one's life, which is in a constant state of change at a velocity that is impossible for teachers to keep up with and adapt. Moreover, it has changed the way people acquire information, enabling them to get access to all kinds of information by just a mouse click away, 24- hours a day, 7-days a week without waiting for anybody to give the information. These emerging trends have somehow tapped their multiple intelligences (MI) and higher order thinking skills (HOTS), making them visual learners, multi-taskers, information analysts, publishers, and real-time learners. The study of [6] emphasized that in order to accommodate these students, educational institutions need to create learning spaces enhanced with technology and service that allow student participation, connection, involvement, and integration.

The e-portfolio is widely accepted as a tool for improving the teaching quality as well as facilitating rapid learning of the students. One can divide the e-portfolios into two large groups, categorizing them as a: 1) "complementary tool for student assessment" and 2) "complementary tool for student reflection. The most outstanding change that we can observe with the e-portfolio as compared to the traditional method is the relative ease with which we can publish the electronically organized content and / or evidence on the internet. Furthermore, such content comes with a personalized design, and in addition allows us to share our ideas with other on-line users throughout the period of learning / reflection [7].

E-portfolio is defined as the digital collections of student's work, which enables the learners to articulate their work, obtain ownership and reflect upon their learning. It can contain artifacts which serve as a personal proficiency matrix, proof of growth, and verification of graduate school students' learning performance. In this study, e-portfolio is utilized as a medium to fuse the course content of Advanced Educational Statistics with key concepts and principles on Education for Sustainable Development (ESD), blended with MI, HOTS and technology.

Additionally, this e-portfolio is a students' activity that allows them to gain educational experiences that go beyond the four corners of the classroom. This type of innovation is very useful and applicable to universities worldwide, especially to Asian regions that are in the furthering progress and advancement on issues related to sustainable development and innovation. Other universities, however, are promoting the use of electronic portfolios for lifelong learning [4].

The nation's quest for economic stability and high-quality life requires people with advanced skills in reasoning, creative thinking, decision-making, and problem solving [8]. To sustain HOTS, universities must undergo curriculum change [9].

Nonetheless, in this process of change, the producers need to integrate their prior knowledge on technology and markets with knowledge about sustainable development, as well as achieve legitimacy for the new innovation the knowledge it entails. This legitimacy must be developed both in the innovating organization, and the community where the innovation will be used [10]. 
Institutions of higher education are exploring means to integrate sustainability into the curricula $[11,12]$. Teachers need to find connections of ESD concepts to technology (e.g. using eportfolio) in preparing their students for the future. If education can serve as the passport for a promising future, then definitely ESD concepts must be included in the curriculum on Higher Education to train them for a future that is sustainable and reasonable.

Furthermore, the applications from the web can be improvised to serve as a menu in students' e-portfolio (Web tools blended with MI, HOTS, and ESD principles). Included in this study are the Blogs, wikis, etudes, merlot, video/photo-sharing, social networking, and other educational web services.

\section{METHODOLOGY}

This study employed a descriptive-correlation design. To determine the significant relationship between students' attitude in cyber portfolio and their performance in Statistics, Spearman Rho was employed.

In the research process, the researcher conducted an online assessment survey to obtain the data necessary for the study. To come up with the intended educational product, this research study underwent three stages. These were the (1) design stage, (2) implementation stage and (3) evaluation stage. The first stage was referred to as the actual making of the course syllabus.

The respondents of the study were the population of forty-four (44) master's degree students who were officially enrolled in Mindanao State University (MSU) and Notre Dame of Marbel University. In addition, the results were interpreted using the following rating scales:

$\begin{array}{cl}\text { Scale } & \text { Qualitative Description } \\ 4.21-5.00 & \text { Very Positive Attitude } \\ 3.41-4.20 & \text { Positive Attitude } \\ 2.61-3.40 & \text { Slightly Positive Attitude } \\ 1.81-2.60 & \text { Negative Attitude } \\ 1.00-1.80 & \text { Very Negative Attitude }\end{array}$

Finally, the researcher designed a proposed menu on MI and HOTS for graduate schools like Mindanao State University and Notre Dame of Marbel University, which was based from the findings of the study.

\section{RESULTS AND ANALYSIS}

Table 2 shows the results of the online assessment. Forty (40) out of forty-four (44) students commented that the teachers' cyber portfolio is a very effective manageable tool that enhances their capability to employ latest educational technology. For instance, they are able to navigate with different environment and add some of these ideas as artifacts to their e-portfolios. As a result, students were excited to update their e-portfolios. For illustration, a student commented:

"I researched for ideas and examples in Statistics so I can use them as a platform in gaining knowledge on Education for sustainable development ....Fortunately; I was able to consign some of these important documents hooked on my e-portfolio making me energized and eager to search for more... 
Table 2. Students' Attitudes toward Cyber portfolio

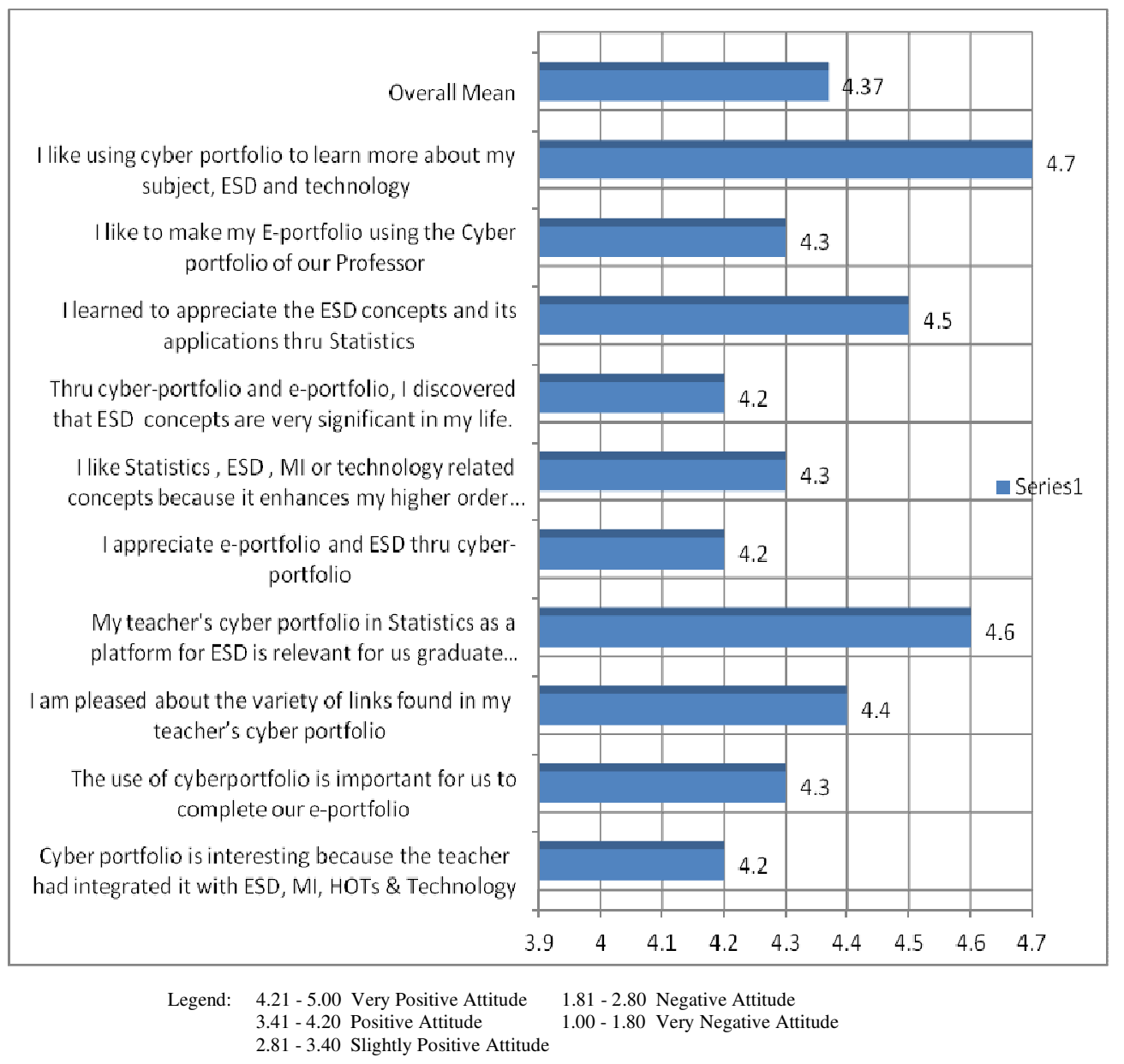

Findings also showed that the over-all students' attitude in a cyber portfolio is $\mathbf{4 . 3 7}$ which is described as "Very Positive Attitude" and that the performance level of graduate school students who were located from different places in Mindanao taking Advanced Educational Statistics generally showed "Very Satisfactory" performance.

Additionally, most of the students had reported that they like using cyber portfolio to learn more about Statistics, ESD and technology $(x=4.7)$ and were pleased about the variety of links found $(x=4.4)$ in the teacher's cyber portfolio to sustain the content of their e-portfolios. This indicates that they are able to navigate through a variety of activities enriched with ESD, MI, HOTS and technology. This further implies that students are able to gain sufficient information, which is pre-requisites to the development of their e-portfolio. This process of linking artifacts into their e-portfolios is inspiring. However, it must be noted that the significance of ESD, HOTS, MI and technology integration as a strategy to learning will have to be highlighted at the introductory stage of the course by the teachers. Table 3 presents the correlation between the students' attitude and performance of the students. 
Advanced Computing: An International Journal ( ACIJ ), Vol.2, No.6, November 2011

Table 3 . The Correlation between Students' Attitude and Pertormance

\begin{tabular}{|c|c|c|c|c|}
\hline & & & Attitudes & Pefformanoe \\
\hline \multirow[t]{6}{*}{$\begin{array}{l}\text { Spearman's } \\
\text { rho }\end{array}$} & Attitudes & Correlation Coefficient & 1.00 & $.498(\mathrm{~m})$ \\
\hline & & Sig. (2-tailed) & & 1 \\
\hline & & $\mathbf{N}$ & 44 & 44 \\
\hline & Peformance & Correlation Coeffibient & $498(x)$ & 1 1.00 - \\
\hline & & Sig. (2-tailed) & 001 & \\
\hline & & $\mathrm{N}$ & 44 & 44 \\
\hline
\end{tabular}

Using a non-parametric correlation, Spearman Rho, the results showed that there is a strong positive relationship $(\mathrm{r}=.498)$ between the students' attitude in the cyber portfolio and their performance in Statistics subject; and that their relationship is significant.

The results of this paper further indicate that the creation of cyber portfolio as teachers' management tool to track and evaluate students' e-portfolio is feasible in MSU and NDMU. However, the implementation of cyber portfolio and e-portfolios suggests that such usage would oblige the HEIs, culture change on students, teachers and staff. The transition from the conventional to the outcome-based assessment model must be initiated with prudence. Not only will the teachers have to accept the task of designing a cyber portfolio, but they will also have to spend extra time tailoring their existing courses. Indeed, the realization of cyber portfolio for students' e-portfolio will necessitate an extensive course re-alignment.

For students, this cyber portfolio is needed to guide them in the completion of their e-portfolio. In the case of Newcastle University, a home-grown e-portfolio was developed and successfully applied with Nursing, Medicine, and Professional Education students [13]. Even so, the use of eportfolio in integrating MI, and HOTS to a student's e-portfolio creates certain issues such as the time factor.

In MSU - General Santos City and NDMU- Koronadal City, the first application of cyber portfolio for a student's e-portfolio, has encountered challenges and finally overcome certain technological issues, such as downloading other files or movies relevant to ESD. Nevertheless, there is a big potential for execution of cyber portfolio in an online format. It is believed that as technology progresses, cyber portfolio would become healthier as it has been the case in MSU and NDMU.

The choice of online implementation of cyber portfolio and e-portfolios require certain technological proficiency of both teachers and students. With this innovation, it is proposed that teachers must learn how to effectively design their cyber portfolio blending Statistics with ESD, MI, HOTs and technology; while students must develop HOTS in the process of collection, selection, and evaluation for their e-portfolio. Thus, it is suggested that teachers ought to develop their own assessment skills and styles towards quality of e-portfolios, assuring ESD as a process that builds HOTS, MI, technology and multimedia than the usual conventional grading of students' assignments in Statistics.

Furthermore, the results of the study showed that the construction of cyber portfolio for eportfolios blended with is achievable, and can promote quality assessment. Later, it was found out that it can speed-up the teaching-learning process if and only if both students and teachers are 
convinced about the effectiveness of cyber portfolio and e-portfolio. The following are the suggested innovative menu for sustainable development:

\subsection{Innovating Menu Blended with HOTS}

When preparing a menu for graduate school students' e-portfolio, it is necessary that these key questions are answered to verify the level and extent to which higher order skills are integrated: (1) Are students encouraged to externalize ideas or knowledge in their own ways? (2) Does the activity find in the menu pose questions that are focused on higher-order thinking skills? (3) Does the web tool in use support the activity at a higher-order thinking skills level?

The suggested menus that incorporate technologies to promote higher-order thinking are shown in Table 4.

\section{Table 4. SUGGESTED MENUS FOR HOTS}

\begin{tabular}{|c|c|c|}
\hline HOTS & Sample Learning Activities & Menu \\
\hline$\frac{\frac{n}{2}}{\frac{\pi}{2}}$ & $\begin{array}{l}\text { 1. Make a questionnaire to gather information about Education for } \\
\text { Sustainable development (ESD). } \\
\text { 2. Conduct an investigation on the three principles of Sustainable } \\
\text { Development to support a view on "ESD". } \\
\text { 3. Make a survey relative to the teaching of Statistics as a platform for } \\
\text { integrating ESD concepts, principles and issues. }\end{array}$ & $\begin{array}{l}\text { Blog post } \\
\text { question on } \\
\text { concepts, Wiki, } \\
\text { Etudes } \\
\text { Classblogmeister }\end{array}$ \\
\hline 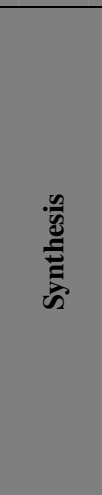 & $\begin{array}{l}\text { 1. Formulate creative solutions or action plans for graduate students as } \\
\text { "agents for change". } \\
\text { 2. Design a case study on ESD principles } \\
\text { 3. Create a new concept or strategy. Give it a name and facilitate an ESD } \\
\text { networking which allows learners to establish partnership with the } \\
\text { NGOs and GOs. } \\
\text { 4. Write about your feelings in relation to ESD principles and reflect on } \\
\text { them your social, environmental and economic responsibilities. } \\
\text { 5. Write a TV show, play, puppet show, role play, song or pantomime } \\
\text { about ESD. }\end{array}$ & $\begin{array}{l}\text { Microblogging } \\
\text { Twitter } \\
\text { Merlot } \\
\text { Blogs (for } \\
\text { reflections } \\
\text { on a } \\
\text { science } \\
\text { project } \\
\text { Making of Group } \\
\text { Wikis on } \\
\text { classtools. } \\
\text { net } \\
\text { Jorum }\end{array}$ \\
\hline 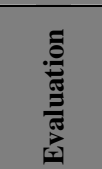 & $\begin{array}{l}\text { 1. Prepare a list of criteria to judge an intercultural game of peace. } \\
\text { 2. Critique violence and prevention of violence in schools. } \\
\text { 3. Conduct a debate about an issue on Sustainability. } \\
\text { 4. Form a panel to discuss views on "ESD." }\end{array}$ & $\begin{array}{l}\text { E-mail, blogs, } \\
\text { Facebook, } \\
\text { Flickr } \\
\text { Teaching wiki }\end{array}$ \\
\hline
\end{tabular}

\subsection{Innovating Menu Blended with MI, Technology and ESD}

Technology has changed the face and function of modern society. The world has become technologically advanced, and our classrooms are gradually following the same advancements. The study of [14] highlighted that means of communication change together with improving technology, and a number of social networks, where communication is established, are rapidly increasing.

Moreover, today's multimedia which is a cautiously woven combination of text, sound, animation, and video elements are now very interactive. This makes learning more engaging, enjoyable and effective. 
Multimedia is defined as the exciting combination of computer hardware and software that allows you to integrate video, animation, audio, graphics, and test resources to develop effective presentations [15].

As technology becomes more inexpensive, accessible, and user-friendly, teachers are also learning how technology and multimedia applications can be used as a dominant instructional tool. Commencing a constructivist learning approach, the integration of multiple intelligences and technology and multimedia is an excellent way to actively engage a student in quality learning. As such, multimedia must be outstandingly well designed.

Thus, the purpose of innovating menu blended with MI, technology and multimedia is to combine its principles creating a recipe with the latest web tools available on the net. The suggested menus that incorporate technologies to promote MI are shown in Table 5.

\section{Table 5. SUGGESTED MENUS FOR MI}

\begin{tabular}{|c|c|c|}
\hline MI & Multimedia/Technology/Activities & Menu \\
\hline 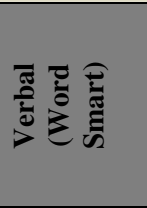 & $\begin{array}{l}\text {-Word puzzles on the different terminologies used in ESD } \\
\text { - Programs that allow children to create stories, poems relative to ESD } \\
\text { - Links on the different poems related to peace building } \\
\text { - Search for blogs that contains concepts on ESD }\end{array}$ & $\begin{array}{l}\text { Blogging } \\
\text { Forums } \\
\text { Wiki } \\
\text { Compositions } \\
\text { Merlot } \\
\text { EdtechTalk }\end{array}$ \\
\hline 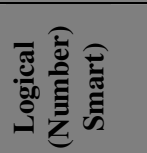 & $\begin{array}{l}\text {-Identifying and sequencing the possible reason for environmental degradation. } \\
\text { - Computer Aided designs fused with ESD principles } \\
\text { - Critical thinking programs }\end{array}$ & $\begin{array}{l}\text { Wiki } \\
\text { Widget Finding } \\
\text { CreatingTimeline } \\
\text { in Slideshare }\end{array}$ \\
\hline 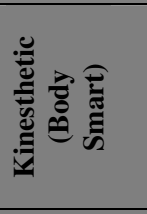 & $\begin{array}{l}\text { - Role playing that examines social relationships and interdependencies at local } \\
\text { and global levels } \\
\text { - Pantomime on social, economic and environmental development related } \\
\text { issues } \\
\text { - Action Drama that promotes "reconciliation" } \\
\text { http://www.media.mit.edu/starlogo } \\
\end{array}$ & $\begin{array}{l}\text { YouTube } \\
\text { Videolectures.net } \\
\text { Scavenger Hunt } \\
\text { TeacherTube }\end{array}$ \\
\hline 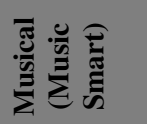 & $\begin{array}{l}\text { - Song composition on Human Rights or Peace } \\
\text { - Band-in-a-Box (PG software) } \\
\text { - Singing software (Transforms to voice input into synthesizer sounds) }\end{array}$ & $\begin{array}{l}\text { LibriVox } \\
\text { Audio Editing } \\
\text { Facebook }\end{array}$ \\
\hline 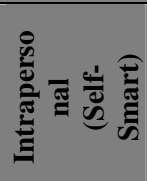 & $\begin{array}{l}\text { - Debate on sustainability principles } \\
\text { - Career counseling software (The Perfect Career) } \\
\text { - Inspiration or kidspiration } \\
\text { - Reflection on Social responsibility }\end{array}$ & $\begin{array}{l}\text { Reporting on } \\
\text { Issues } \\
\text { Fora.tv } \\
\text { Reflecting Activity } \\
\text { dgCommunities }\end{array}$ \\
\hline 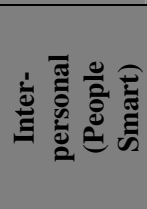 & $\begin{array}{l}\text { - Electronic bulletin boards on ESD (Kidsnet) } \\
\text { - Simulation games (Sim City) } \\
\text { - E-mail programs (Outlook, Eudora) } \\
\text { - Discussions on ESD and over population }\end{array}$ & $\begin{array}{l}\text { Forums } \\
\text { /Discussions } \\
\text { Blogging } \\
\text { LectureFox } \\
\text { Chatting/Email/ } \\
\text { Facebook }\end{array}$ \\
\hline 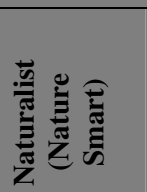 & $\begin{array}{l}\cdot \text { Photo paint of Mother earth } \\
\cdot \text { 3D software that portrays nature } \\
\cdot \text { Software games fused with ESD } \\
\text {-Multimedia authoring programs on Sustainability }\end{array}$ & $\begin{array}{l}\text { Photography } \\
\text { Gcast } \\
\text { Maps } \\
\text { Storyboarding }\end{array}$ \\
\hline
\end{tabular}




\section{CONCLUSION}

This research indicates that the graduate school students appreciate the teaching and learning experiences. These technologies enhance the learning process, and satisfy different types of learners. They take their teachers' cyber portfolio as a means to enrich their learning experience. Graduate school professors can learn from the ways graduates use e-portfolio for self-study and enforce current strategies to help students innovate. Further research is needed to determine the ability of professors to use cyber portfolio for learning in the context of their syllabus. It is also important to identify the learning goals when employing e-portfolio or cyber portfolio for teaching and learning purposes and to compare the benefits of new technologies across disciplines. Despite the sample size, survey pilot described here offer an indication of the master's degree students of the usefulness of innovative technologies to their learning experience.

In the light of the findings, the following conclusions could be made:

1. The students have a "Very Positive Attitude" towards cyber portfolio as a tool for blending Statistics with ESD, MI, HOTs and technology

2. The graduate students have a Very Satisfactory level of performance in Statistics.

3. There is a strong positive relationship between the students' attitude in a cyber portfolio and their performance in Statistics. Furthermore, results revealed that there is a significant relationship between the students' attitudes towards cyber portfolio and their performance in Statistics.

Moreover, the growing use of e-portfolio necessitates cyber portfolio as an administrative tool for monitoring students' e-portfolio. This can be a dashboard, or a blog of a class website for linking students' e-portfolio and has specific menu functionality designed to link students' portfolio and showcase different menu blended with ESD, HOTS, MI and technology and multimedia.

The results of the study have also shown that the construction of cyber portfolio for e-portfolios is achievable, and can promote quality assessment. Later, it was also found out that it speeds-up the teaching-learning process provided that students and teachers are convinced of its effectiveness into the course.

In view of the findings of this study, suggested samples on how to innovate a menu blended with ESD, HOTS, MI and Technology were given in the Asian context. It is hoped that this process will not only improve cyber portfolio itself, but it will also enhance teacher-student academic exchange towards effective life-long learning.

Henceforth, the author viewed this experience, as a positive accomplishment as she discovered its usefulness as a cyclical follow-up tool. On a personal point, it can serve as summarized authentic output of students, where they could present it to display their abilities, even though time and effort were invested in order to attain the maximum yield of this tool.

\section{ACKNOWLEDGMENTS}

The author wishes to extend her sincere gratitude to Dr Julnes U. Jumalon, the NDMU and MSU Administration for the assistance that they have extended. She also would like to thank the Commission on Higher Education (CHED) for the sponsorship of her participation to the 2011 International ICCISD Conference, Kuala Lumpur, Malaysia. 


\section{REFERENCES}

[1] Krueger, A.B. \& Mikael Lindhal (2001), 'Education for Growth, Why and for Whom?' Journal of Economic Literature Vol. 39, no. 4 pp. 1101-136.

Lancaster University (2008) MyPlace Lancaster University [online] Accessed 3 April 2010 from http://www.lancs.ac.uk/celt/celtweb/students_myplace

[2] Dike,V.E. (Jan-March, 2002),'The State of Education in Nigeria and the Health of the Nation,' NESG Economic Indicators, Vol. 8, No 1.

[3] Internet World Statistics. [Online] Accessed 3 June 2011 from http://www.internetworldstats.com/stats.htm

[4] Aliweh, Ahmed Mahmoud (2011). The Effect of Electronic Portfolios on Promoting Egyptian EFL College Students Writing Competence and Autonomy. Asian EFL Journal (OnLine). Accessed 2 June 2011 (http://www.Asian-EFL-Journal.com/site_map2011.php)

[5] Wilkinson, Susan C. (2011). Using socially constructed technology to enhance learning in higher education. Journal of Learning Development in Higher Education (Online) Accessed 3July 2011 (http://www.uh.cu/static/documents/RDA/Using\%20socially\%20constructed\%20technology.pdf)

[6] Byas, Trikartikaningsih. E-Portfolios and Student Wiki Interdisciplinary Group Project. Accessed October 2011 (http://lams2011.lamsfoundation.org/pdfs/TByas_LAMS2011.pdf).

[7] Rodriguez-Donaire, S. \& García, B. Web 2.0 As An E-Portfolio Tool. Technical University of Catalonia Barcelona, Spain. Accessed 2 June 2011 http://upcommons.upc.edu/eprints/bitstream/2117/12716/1/rodriguez\%20-\%20amante.pdf

[8] Ganaden \& Ramirez (2008) "Creative Activities and Students' Higher Order Thinking Skills", EDUCATION QUARTERLY, December 2008, Vol. 66 (1), 22-33 U.P. College of Education

[9] Ransom, Scott (2010) "Building Higher Order Thinking Skills in Tomorrow's Health Care Professionals" University of North Texas Health Science Center

[10] Bresman, H., \& Sölvell, Ö. (1997) 'Local and global forces in the innovation process of the multinational enterprise - an hour-glass model'. NORDREFO 1997:3. Special issue: Regional Specialisation and Local Environment - Learning and Competitiveness.

[11] Cusick, J. (2009), "Study abroad in support of education for sustainability: a case study", Environment, Development, and Sustainability, Vol. 11 No. 4, pp. 801-13.

[12] Rusinko, C.A. and Sama, L.M. (2009), "Greening and sustainability across the management curriculum: an extended journey”, Journal of Management Education, Vol. 33 No. 3, pp. 271-5.

[13] Wijnand, A. (2004) Digital portfolio: tool for Flexible Learning and teaching in competency focused highereducation. In M. Veugelers \& A. Wijnand (Eds.), Electronic Portfolio in the Netherlands; Some Articles, p. 7 - 14. Utrecht: Sticht-ing SURF. [online] Accessed 6 June 2010. http://www.e learning.surf.nl/docs/portfolio/electronic_portfolio_in_the_netherlands.pdf

[14] Çakır, O \& Kayri1 M (2010) . An Applied Study On Educational Use Of Facebook As A Web 2.0 Tool: The Sample Lesson Of Computer Networks And Communication [Online] Accessed 15 January 2011. International Journal of Computer Science \& Information Technology (IJCSIT) Vol.2, No.4, August 2010.

[15] Fenrich, P. (2002). An Instructional Model for Teaching Troubleshooting Skills. Proceedings of the Informing Science and IT Education Conference 
Advanced Computing: An International Journal ( ACIJ ), Vol.2, No.6, November 2011

\section{Dr. Ava Clare Marie O. Robles}

Dr. Robles is an Associate Professor IV in Mindanao State University, Philippines. She had been an International paper presenter in Thailand and Malaysia, authored three books and a Graduate School professor in Mindanao State University and Notre Dame of Marbel University.

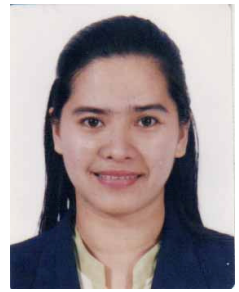

